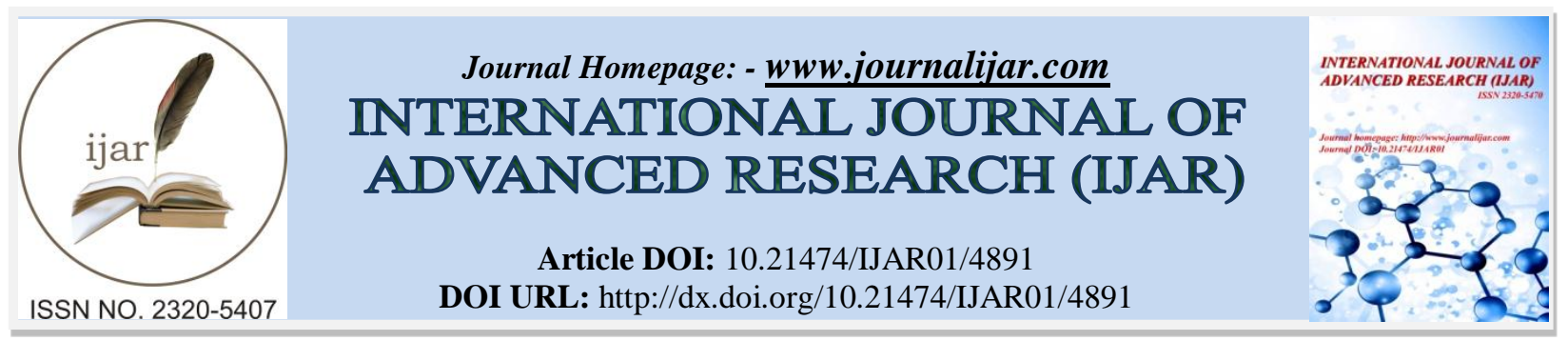

RESEARCH ARTICLE

\title{
EVALUATE THE CROPPING PATTERN IN THE COMMAND AREAS USING SATELLITE REMOTE SENSING TECHNIQUES OF GODAVARI BASIN MAJOR IRRIGATION PROJECTS.
}

\author{
"Dr. Narsimha Kota, Girija Pamu, Ravi Sanatana and M.Suresh. \\ Rural Development Society, R\&D Centre, Prestige Rai Towers, Flat No.404, B-Block, Punjagutta, Hyderabad, \\ Telangana, and India.
}

\section{Manuscript Info}

(.........................

Manuscript History

Received: 19 May 2017

Final Accepted: 21 June 2017

Published: July 2017

Key words:-

Irrigation Potential, Crop Productivity,

Command area, Remote sensing.

\section{Abstract}

India is one among the largest irrigators of the world but, there is an increasing concern over low crop productivity, low water use efficiency and the gap between Irrigation potential created and Irrigation potential utilized. The Kadem, Nizamsagar and Sriram sagar projects located at Adilabad, Nizamabad ,Karimnagar and Warangal districts, in South Telangana, This is constructed the Godavari River basin. Remote Sensing \& GIS tools were effectively employed to assess irrigated crop acreage information right up to Distributary/ Off Take(OT) level. Topography analysis is used for separation of cultivable command area (CCA) and uncommand areas. Landsat -8 and IRS P6 - LISS III, satellite data before construction of the Reservoir (2009-10, 2010-11) and after Construction of the Reservoir (2014-15 \& 2015-16) is processed for classification of Wet \& Dry crops irrigated under canal and that irrigated by other sources such as Tanks and Groundwater.

The prime objective is to evaluate the cropping pattern in the command areas using satellite remote sensing techniques supplemented with field data during Rabi season of 2015 -16. It is observed that, due to the influence of urban development in some distributaries and conversion of wet crops and fallow land to ID crops there is decrease of wet crops and increase of ID crops. It is observed that GIS and RS techniques of evaluating the project performance are useful for decision making regarding the water management issues.

Copy Right, IJAR, 2017,. All rights reserved.

\section{Introduction:-}

Monitoring and evaluation of irrigation command with regard to water management and agricultural productivity is vital to know the resource, environment and the returns from the investment. It is realized that a substantial gap exists between irrigation potential created and potential utilized. Irrigation planning and management involves knowledge of both the total demand and the distribution of demand for irrigation water over space and time. The major information required for irrigation studies is about crop type, crop acreage, crop condition and crop yield. From this information estimates for water demands can be made. Because of the time constraints, dynamic changes and vast areas involved, Remote Sensing is found to be an effective tool for irrigation studies compared to conventional methods which are point based, time consuming and cumbersome.

Corresponding Author:- Dr. Narsimha Kota.

Address:- Rural Development Society, R\&D Centre, Prestige Rai Towers, Flat No.404, B-Block, 
Remote sensing techniques are cost and time effective to provide objective primary information of cropping pattern, cropping intensity, crop acreage, crop productivity, water logging and soil salinity/alkalinity, irrigation area utilization on the spatial and temporal scales. This helps in comparative performances, evaluation and identifying problem areas within the command for corrective management measures.

\section{Objective:-}

The prime objective is to evaluate the cropping pattern in the command areas using satellite remote sensing techniques supplemented with field data during Rabi season of 2015 -16.

Assessment of irrigated cropped area using high resolution satellite data.

\section{Study Area:-}

The study covers all the existing 3 Major irrigation projects under Godavari basin of Telangana State. The part of Godavari basin has 3 Major and 20 Medium irrigation projects and the part of Krishna basin has 4 Major and 13 Medium irrigation projects. The Figure-1 shows the spatial extent of the command areas. Table 1 shows the details of Major Projects, such as Ayacut, Mandals \& Villages covered.

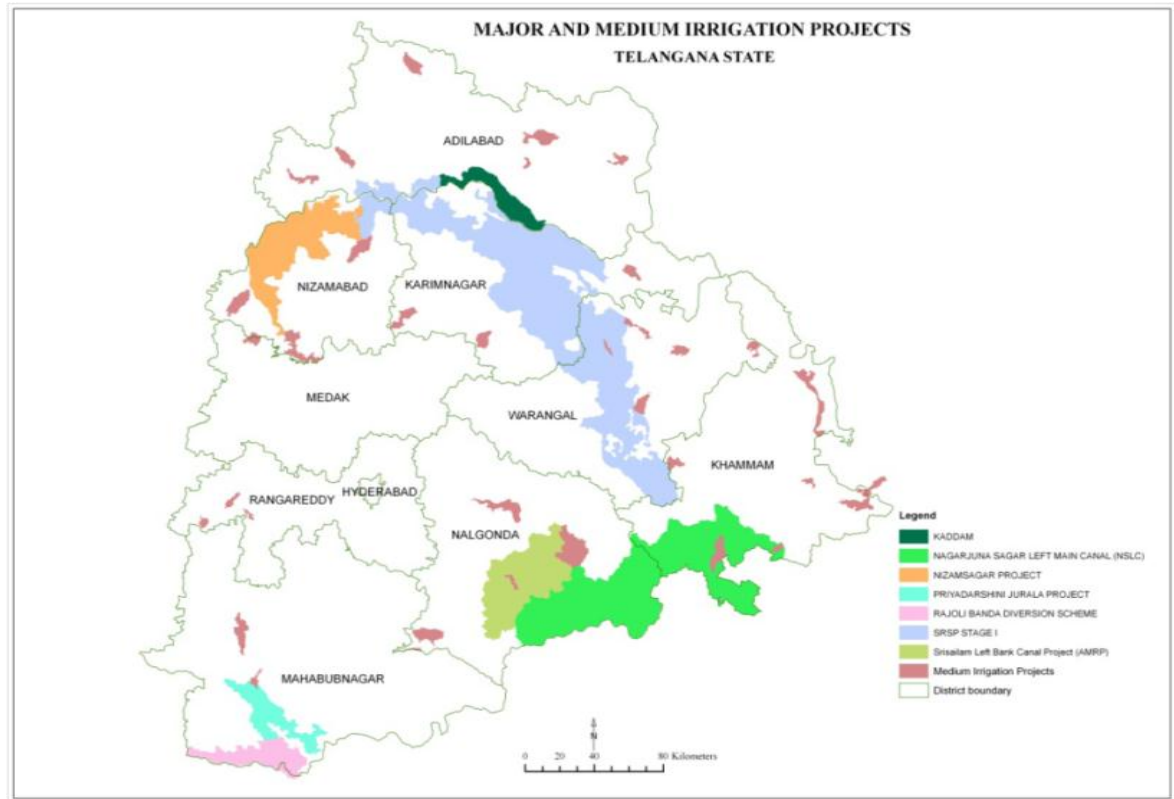

Fig 1: -shows the spatial extent of the command areas.

Table 1:- Details of Ayacut, Mandals \& Villages covered in Major Irrigation Projects

\begin{tabular}{|l|l|l|l|}
\hline Major Projects & Total Ayacut (ha) & Mandals & Villages \\
\hline Kaddam Narayan Reddy Project & 27,530 & 5 & 112 \\
\hline Nizamsagar Project & 93,660 & 19 & 355 \\
\hline Sri Ram Sagar Project (SRSP) & $3,87,265$ & 81 & 1065 \\
\hline Total & $\mathbf{5 , 0 8 , 4 5 5}$ & $\mathbf{1 0 5}$ & $\mathbf{1 5 3 2}$ \\
\hline
\end{tabular}

Data Used:-

GIS Layers

Remote Sensing Data

mmand Area Boundaries

Landsat - 8, OLI_TIRS data of 23 rd February 2016

\section{Methodology:-}

The command area boundaries of each project have been delineated based on available maps gathered from the field offices of the respective projects. Wherever the maps are not available the command boundaries are demarcated based on cropping pattern and terrain characteristics, interpreted with the help of satellite data and drainage pattern of the area. Remote Sensing \& GIS tools have been employed for the cropping pattern analysis. 
Landsat - 8, OLI_TIRS data of 14th, 16th February and 23th February is classified to identify for each command the spatial extent of Wet and irrigated dry (ID) crops. Multi date interpretation is performed on available satellite data, so as to avoid cloud cover and analyse the best reflectance available in either of the images. The Interpretation is validated using the Ground Truth data. The performance indicators viz. Equivalent Wet area for all the projects has been estimated.

\section{Analysis \& Observations:-}

The total command ayacut of Major and Medium Irrigation projects of Telangana State is 10.83 lakh ha. The command ayacut of Major and Medium Irrigation projects is $9.43 \%$ of the total geographical area of Telangana State. Major three projects total ayacut area in Godavari basins of Telangana State is 5,08,455 ha covered by 105 mandals / 1532 villages either totally or partially.

\section{Godavari basin - Major Projects:-}

The Godavari basin of Telangana has 3 Major irrigation projects with command ayacut of 5.08 lakh ha covered by 105 mandals / 1532 villages. In Telangana State out of the total irrigated area by major irrigation projects $54 \%$ of the irrigated area is contributed by Godavari Basin.

\section{Kaddam Narayan Reddy Project:-}

The Kaddam project is constructed across Kaddam River which is a tributary to the Godavari River. The project is located near the Peddur (V) Kaddam (M) in Adilabad District. The project GCA is 58,300 ha out of which the total ayacut is 27,530 ha and is covered by 5 mandals /112 villages of Adilabad District. In Godavari Basin of Telangana, out of the total area irrigated by major irrigation projects, Kaddam project contributes $5.4 \%$.

Satellite data analysis in the Kaddam command area for the cropping pattern during Rabi Period of 2015-16 is shown in Figure-2.

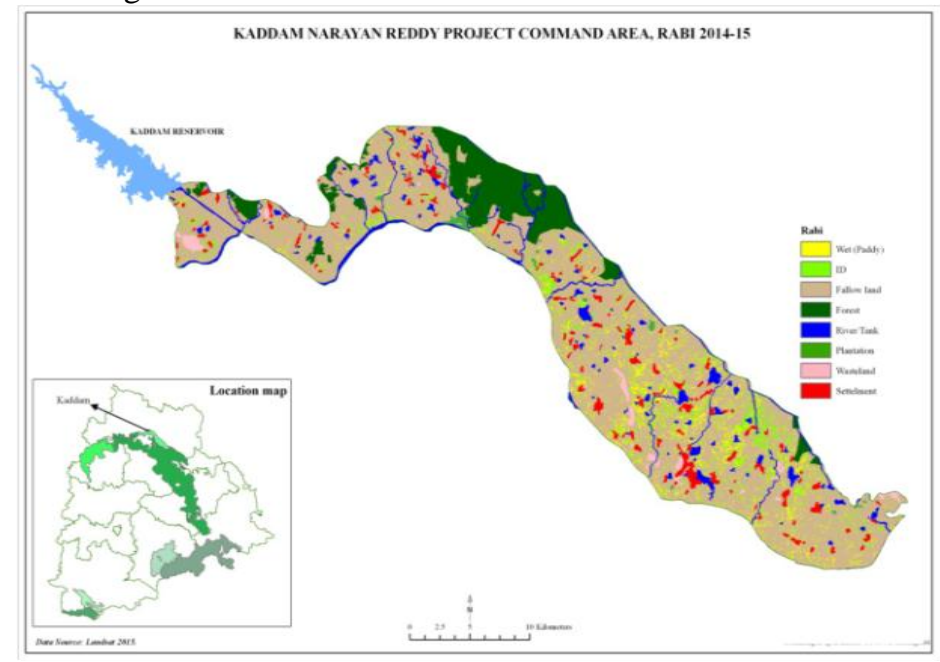

Fig 2:- Classification of Kaddem Project.

\section{Results:-}

$>$ The irrigated area is found to be 6,113 ha out of the total ayacut of 27,530 ha.

$>$ The equivalent Wet area is estimated as 2,943 ha and ID area is estimated as 3,170 ha.

$>$ The total crop area is $22 \%$ of the total ayacut area out of which the wet crop is $48 \%$ and ID crop is $52 \%$ of the total irrigated area.

$>$ The Rabi crop area, for the current year, 2015-16 is 71\% when compared with the previous year 2014-15.

\section{Nizamsagar Project:-}

The Nizamsagar project was constructed across river Manjeera, a tributary of Godavari River in Nizamabad district. The designed ayacut under this project is to provide irrigation facility to 93,660 ha. It is supplying water through the main canal covered by 19 mandals / 355 villages of Nizambad district. The command area starts from Banjepalle in 
Yellareddy mandal. In Godavari Basin of Telangana, out of the total area irrigated by major irrigation projects, Nizamsagar project contributes $18.43 \%$.

Satellite data analysis in the Nizamsagar command area for the cropping pattern during Rabi period of 2015-16 is shown in Figure-3.

\section{Results:-}

$>$ The irrigated area is found to be 70,075 ha out of the total ayacut of 93,660 ha.

$>$ The equivalent Wet area is estimated as 28,563 ha and ID area is estimated as 41,152 ha.

$>$ The total crop area is $75 \%$ of the total ayacut area and the Wet crop is $41 \%$ and ID crop is $59 \%$ of the total irrigated area.

$>$ The Rabi crop area, for the current year, 2015-16 is 88\% when compared with the previous year 2014-15.
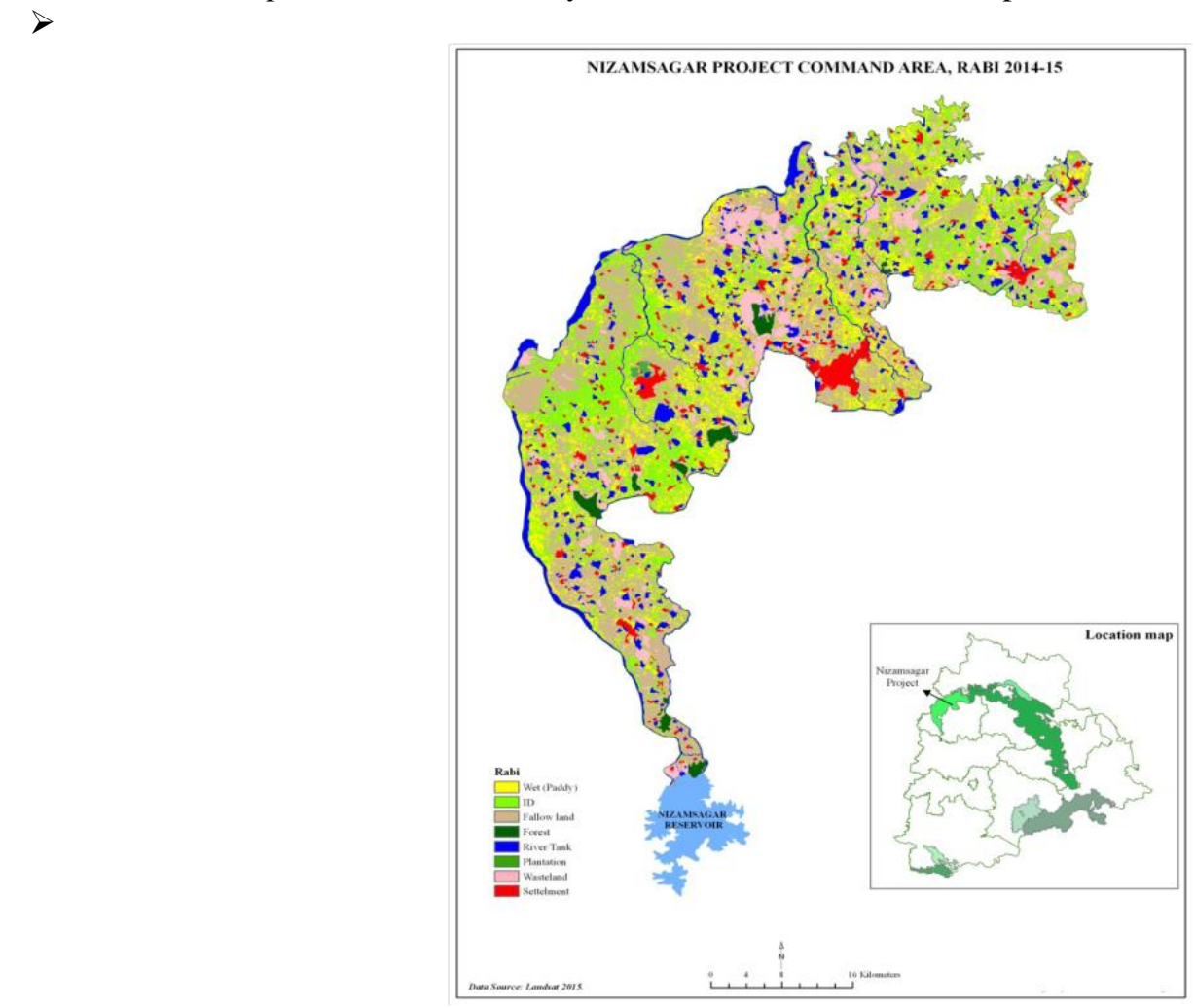

Fig 3:- Classification of Nizamsagar Project

\section{Sriramsagar Project (SRSP):-}

Sriramsagar project (SRSP) is a multipurpose project constructed across the river Godavari near Pochampad village in Balkonda Mandal, Nizamabad District. The project GCA is 9, 13,160 ha out of which the total ayacut is 3, 87,266 ha and is covered by 81 mandals / 1065 villages of Karimnagar, Nizamabad, Adilabad, Warangal and Khammam Districts. In Godavari Basin of Telangana, out of the total area irrigated by major irrigation projects, Sriramsagar project contributes $76.23 \%$. There are four main canals under this project namely Kakathiya Canal, Saraswathi Canal, Laxmi Canal and Kaddam Canal. The project envisaged to provide irrigation facility to an extent of 391736.3 ha under Kakathiya canal, Saraswathi canal and Laxmi canal. In addition to that it provides irrigation under Kaddam project to the extent of 27518.67 ha of localized ayacut. Apart from that some minor irrigation tanks were being fed by the system. Out of 391736.3 ha localized ayacut, about 369073.9 ha is under Kakathiya canal, about 14164.02 ha under Saraswathi canal and 8903.098 ha under Laxmi canal. The total length of the Kakathiya main canal is $284 \mathrm{~km}$. The length of Saraswathi Canal is $47 \mathrm{~km}$. The Laxmi canal is $3.5 \mathrm{Km}$. The Lower Manair dam (LMD) constructed at the confluence of Mohedamada River and Manair River which is a tributary of a Godavari River to drop the Kakathiya canal water at $146 \mathrm{~km}$. 
Generally, the canal water is released from mid July to November/December; during Rabi. In Rabi season water is supplied from December to March/April depending on storage available and crop status. The principal-irrigated crops are paddy, maize and Jowar in the Rabi season, paddy and maize in Rabi season, and cotton, Chillies as the two season crops. The command area spreads five Districts namely Karimnagar, Nizamabad, Adilabad, Warangal and Khammam. Satellite data analysis in the Sriramsagar command area for the cropping pattern during Rabi period of 2015-16 is shown in Figure-4.

\section{Results:-}

$>$ The irrigated area is found to be $1,62,819$ ha out of the total ayacut of 3,87,266 ha.

$>$ The equivalent Wet area is estimated as 64,619 ha, ID area is estimated as 98,170 ha.

$>$ The total crop area is $42 \%$ of the total ayacut area and the wet crop is $40 \%$ and ID crop is $60 \%$ of the total irrigated area.

$>$ The Rabi crop area, for the current year, 2015-16 is 50\% when compared with the previous year 2014-15.

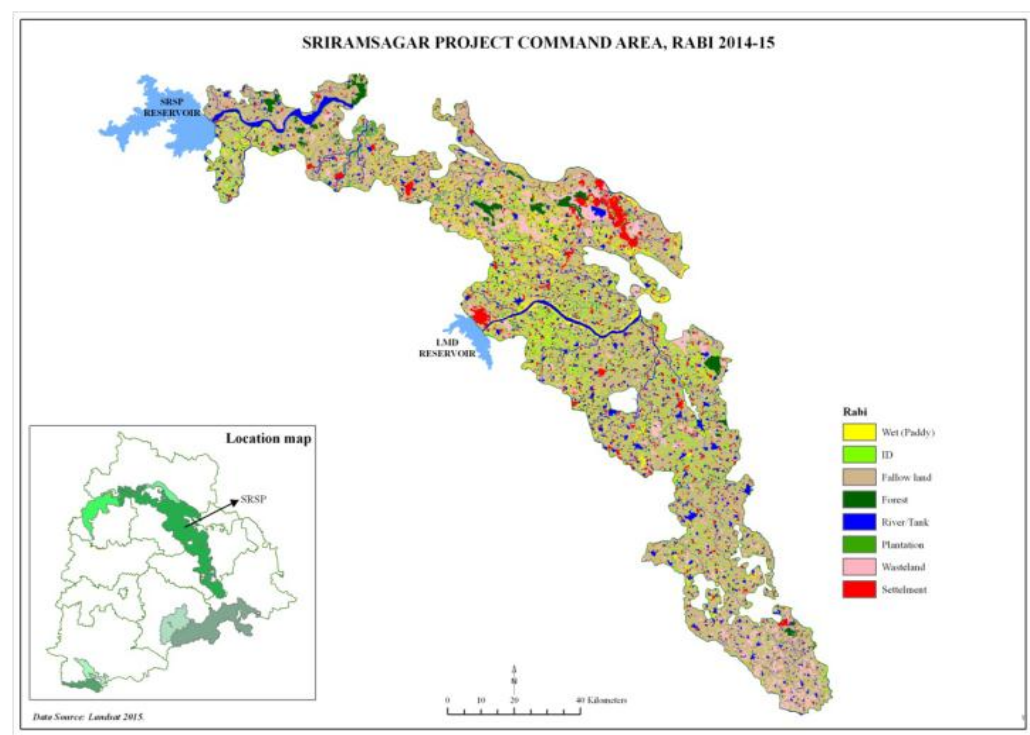

Fig 4:- Classification of SRSP.

\section{Comparative analysis of major Irrigation Projects:-}

A comparative analysis of the satellite remote sensing based command area monitoring of Major and Medium irrigation projects in rabi season for the year 2015-16 is prepared.

- In the current year, 2015-16 Rabi crop area is very low when compared with previous year. The reason for the low crop production in the current year is due to deficient rainfall and there by low reservoir water levels.

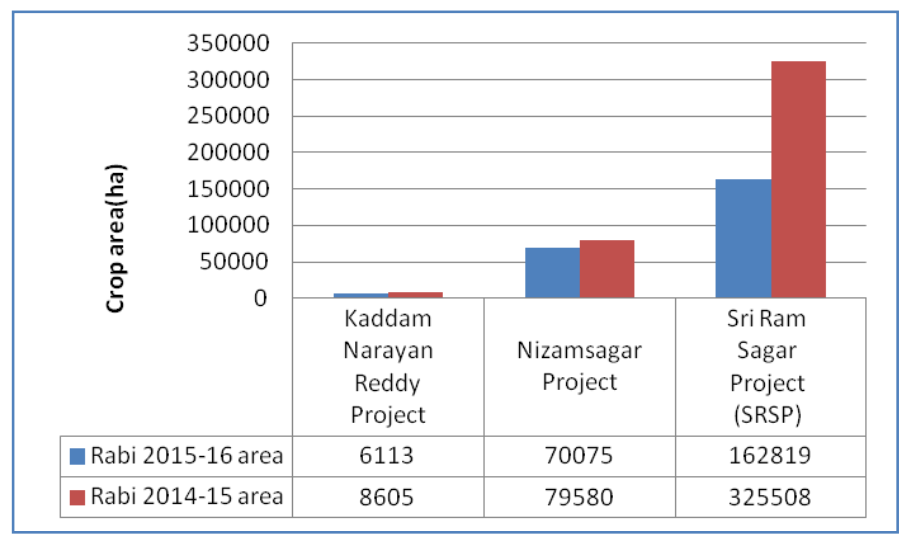


- Comparative analysis of Wet crop, in Rabi season of 20014-15 and 22015-16 has shown that all projects the wet crop area is less than the previous years, for all the major irrigation projects (Graph..2).

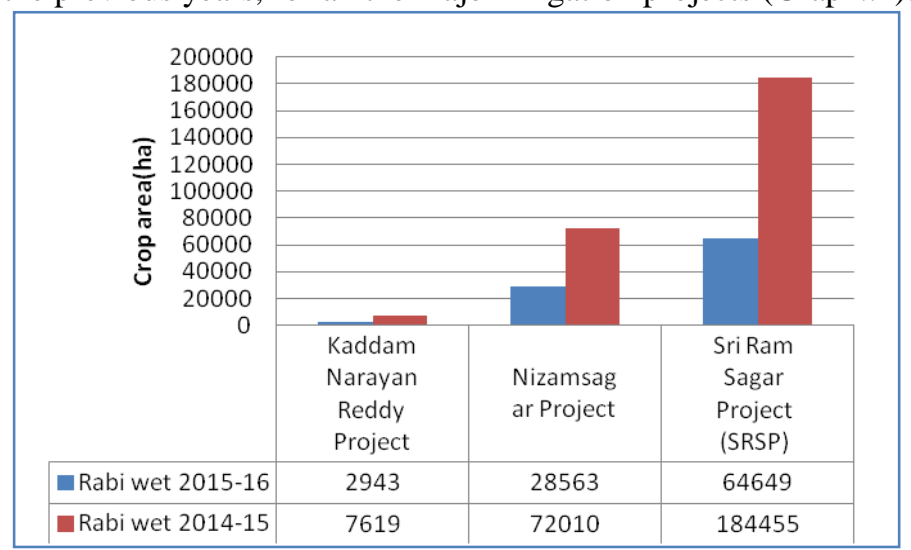

- Comparative analysis of ID crop, in Rabi season of 2013-14 and 2014-15 has shown that except Nizamsagar, Kaddam, projects the ID crop area is less than the previous years, for Sri ram sagar projects (Graph.3).

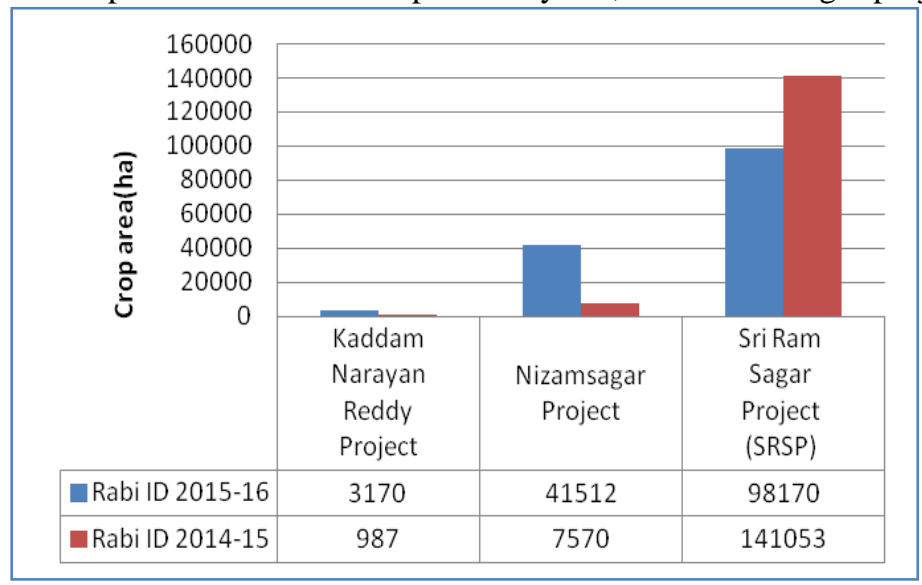

\section{Conclusions:-}

$>$ Kadam Narayan Reddy Project - Comparative analysis of total Rabi crop area, Wet crop and ID crop over last year shows that the total Rabi crop has reduced, thee reduction is in Wet crop area. The total crop area is $22 \%$ of the total ayacut area and the wet crop is $48 \%$ and ID crop is 52\% of the total irrigated area.

> Nizamsagar Project - Comparative analysis of total Rabi crop area, Wet crop and ID crop over last year shows that the total Rabi crop has reduced mainly because of major reduction in Wet crop area, increase in ID crop area. The total crop area is $75 \% \%$ of the total ayacut area and the wet crop is $41 \%$ and ID crop is $59 \%$ of the total irrigated area.

$>$ Sriramsagar Project (SRRSP-I) - Comparative analysis of total Rabi crop area, Wet crop and ID crop over last year shows that the total Rabi crop has reduced mainly because of major reduction in both Wet and ID crop area. The total crop area is $42 \%$ of the total ayacut area and the wet crop is $40 \%$ and ID crop is $60 \%$ of the total irrigated area.

$>$ From the entire study the following conclusions were arrived for the year 2014--15.

$>$ The Rabi crop area is less than the ayacut area for all the major and medium irrigation projects

$>$ The Rabi crop area, in all the major irrigation projects, for the current year, 2015-16 is 61.5\% when compared with the previous year 2014-15.

$>$ The performance of command area of major irrigation projects put in was moderate.

$>$ The major irrigation projects performed well when compared to medium irrigation projects.

$>$ In most of the irrigation projects reduction in ID crop area was more when compared with reduction in Wet crop area. 


\section{Acknowledgment:-}

Authors are thankful to the Rural development society- R\&D centre, Punjagutta and his technical staff for providing valuable help and facilities for conducting this study. Authors are also thankful to the Department of TRAC. for sharing the data and information of the study area.

\section{References:-}

1. Annual Report 2010-11, Irrigation \& CAD Department, Government of Andhra Pradesh.

2. Directorate of Economics and Statistics, Government of Andhra Pradesh. - An Outline of Agriculture Situation in Andhra Pradesh - 2008-2009.

3. Hand Book of Statistics Adilabad District 2015, Compiled and Published by Chief Planning Officer, Adilabad District.

4. Irrigation and Command Area Development, Government of Andhra Pradesh.

5. Prince, S. D. 1991. A model of regional primary production for use with coarse resolution satellite data. International Journal of Remote Sensing 12(6): 1,313-1,330.

6. Satya Prakash Tucker, Sanjay Gupta, Rahul Sen, R.Doraiswamy and Humera Anjum, "Improving Irrigation Performance Management: navigating through Andhra Pradesh experience", I\&CAD Department, Andhra Pradesh, India.

7. Anil Kumar "Application of GIS and RS on Catchment and Command Area Management of Hattikuni Dam, Yadgiri District. By, IJERT-VOL-3

8. N. Kota, N. Ramudu, S. Ravikumar, and M. Suresh, "Hydrogeomorphological Mapping Upto Cadastral Level, By Using High Resolution Satellite Data In Gokaphaslwada Watershed, Doulthabad Mandal, Mahabubnagar District," IOSR Journal of Applied Geology and Geophysics, vol. 5, no. 1, pp. 46-51, Feb. 2014.

9. Jaspal Singh, M.S Acharya, Arun Sharma, "Water Management (Problems and Prospects in Command Area)" ,By: Himansu Publication-Udaipur

10. S.S.Ray, V.K.Dadhwal, R.R. Navalgund "Performance evaluation of an irrigation command area using remote sensing: A case study of Mahi command, Gujarat, India.. Agricultural Water management -ELSEVIER. 